\title{
REGIONAL FEATURES OF THE GLOBAL MARKET OF SYNDICATED LENDING
}

\author{
Nazar MOROZ ${ }^{1}$ \\ Institute of Regional Research named after M.I. Dolishniy of the \\ National Academy of Sciences of Ukraine, Ukraine
}

\begin{abstract}
The purpose of the paper is to explore and analyze of current market trends in the global market of syndicated lending, characterized its regional structure, identify its specific features and characteristics in different regions of the world and defining the main directions of further development of the global market of syndicated lending. Methodology. The research is based on statistical information from public sources from different countries concerning the development of syndicated loans. Data was also obtained from the websites of leading credit rating agencies, exploring the development of syndicated lending. Also, in the study of the issue, analytical articles on the development of syndicated lending in the world were used. Results. The development of syndicated loan market in recent years is characterized by: rapid growth of the volume and number of transactions; international nature; determining influence the US and Western Europe to market dynamics; active actions of international financial institutions in the developing countries markets; simplification of credit agreements conditions; consolidation of basic parameters of the loan - the total transaction amount and term of the loan. The dynamics of the global market of syndicated lending and its profitability determines the ratio between the leveraged and investment grade loans, which development depends on the overall market situation. Based on the analyzed of main factors it was found that in the short term the market will continue to grow, however quite slowly. Practical implications. Research of the syndicated loan market makes it possible to understand more about the mechanism of functioning of the modern financial sector. In our opinion, special attention should be paid to markets in developing countries which have considerable growth potential. Value /originality. It is first time we have grouped countries due to the main aspects of syndicated lending, such as: the amount of the transaction, loan term, the industry and the share of foreign capital in the market. The obtained results of research will contribute to a better use of international experience for building a system of syndicated lending in country, and make possible transforming it into an effective instrument of financing the real economy.
\end{abstract}

Key words: syndicated loans, syndicated lending, market of syndicated lending, commercial bank, development.

JEL Classification: F01, G15, G17, G21

\section{Introduction}

Syndicated lending has become increasingly popular at the present stage of development of global economic relations. Along with the issue of shares and bonds, syndicated loans have become a powerful source of financing of the current activities and the implementation of large-scale investment in the development of economic entities. The largest loan agreements determining the further development of transnational corporations are taking place on the market of syndicated lending. These circumstances determine the relevance of the research of problems related to the optimization of commercial banks lending for the development of syndicated lending. At the same time, studying of issues related to the organization of this type of lending intensified under the influence of globalization and the asymmetries of development of financial markets, increasing competition, both in the domestic and global banking space. Building an effective system of syndicated lending requires active use of foreign experience. At the same time, foreign approaches should be used extremely carefully, taking into account, as the national features of construction of the banking system, and features countries with extensive using of syndicated loans. Among the foreign and domestic scientists, there are many scholars who examined patterns of development of syndicated loan market, its nature and structure. Special attention deserve the works of such scholars as Karl Dawson, M. Campbell, T. Rhodes, A. Taylor, A. Fait, J. Levkovsky, S. Tsyganov, V. Mishchenko, N. Panteleeva, A. Yanshina and others. In the reviewed literature sources the essence and principles of syndicated lending are disclosed, the impact of certain factors on its development

\footnotetext{
Corresponding author:

${ }^{1}$ Institute of Regional Research named after M.I. Dolishniy of the National Academy of Sciences of Ukraine.

E-mail: nazar789@gmail.com
} 
are analyzed, as well as various economic and legal aspects of the organization of syndicated transactions. At the same time, features of the functioning of the global market of syndicated lending in a particular region of the world are still scarcely explored.

\section{The role of the syndicated loan}

Syndicated loan is a loan provided by two or more creditors, organized on the basis of a multilateral agreement in the banking syndicate, one or more borrowers, in order to ensure concentration of financial resources without increasing the additional risk of lenders.

The commitment of governments, corporations and banks to syndicated lending in comparison with other forms of financing is explained by a combination of the most attractive features of commercial and investment banking practices. Based on studies of the essence of syndicated lending and comparing it with a bilateral lending, we can distinguish a number of benefits to the participants of credit relations. In particular, for borrowers we can define the following benefits: the possibility of obtaining a much greater loan amount than in the bilateral lending; speed of getting and credit services; the presence of common conditions; reducing the risk of dependence on a single lender and expanding common database of partner banks; increasing business reputation in the market; opportunities of outputs in the international markets, etc.

Lenders involved in the syndicate, also receive a number of benefits, among them - the simplicity and the speed of formation of assets; diversification and minimization of credit risks; reduction of additional costs on the marketing activities and savings on transaction costs; obtaining additional income in the form of commissions; the expansion of the customer base; improving the business reputation; increasing liquidity of assets, etc.

\section{Development of the global market of syndicated lending}

The market of syndicated lending originated in the 60 s of the last century and during the last decades has acquired a considerable scale. For instance, during 2015 on the global market for of syndicated lending were held for more than ten thousand transactions totaling USD 4,662 bn (Figure 1). Together with the increased volumes of syndicated loans, rose their share in the financial sources compared with stocks and bonds. In particular, if in 1993 the share of syndicated loans in the structure of funding sources was approximately $10 \%$, in 2003 - at $35 \%$, in 2013 nearly $45 \%$ of all long-term resources raised on the financial capital markets, accounted for the syndicated loans (World Bank, 2015).

The essence of the global market of syndicated lending as a specific sphere of international economic relations, and part of the global market consists in the organization of the legislative system of relations between its subjects for purchase and sale of the specific nature of the services, channeling financial resources from the owners to the borrowers. The modern market of syndicated lending is provided by the existence of multinational financial institutions, which act as intermediaries in the redistribution capitals and provide the continuity of the process of economic reproduction.

One of the most important elements determining the order of relations between participants in lending is the credit rating of the borrower. Information for its definition is taken from the leading rating agencies - Standard and Poor's, Moody's and Fitch. Number of essential terms of the loan (interest rate, term, collateral type, a list of standard covenants, etc.) depends on the credit rating.

Most of the information and analytical agencies, as well as scientists in their studies, depending on the assigned credit rating share loans to the two groups:

1. Investment-grade loans - are granted to borrowers whose credit rating are highly rated (BBB- or higher by Standard and Poor's, Baa3 or higher by Moody's Investors Service, and/or BBB- or higher by Fitch Ratings). These companies tend to be large, established, and profitable, and usually obtain their long-term financing from the issue of bonds or commercial paper, which are cheaper methods for them. However, they borrow by way of syndicated loans in the form of revolving credit as back-up

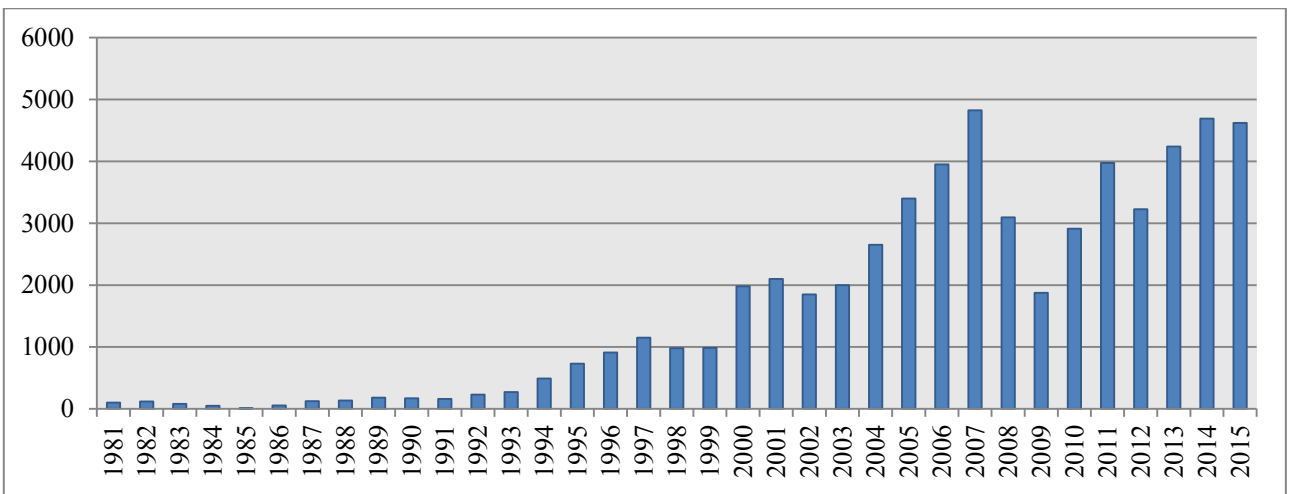

Fig. 1. Dynamics of the global market of syndicated lending, USD billions

Source: Bloomberg Finance L.P., 2015, World Bank, 2015, Thomson Reuters, 2015 
for seasonal borrowing needs, backstop commercial paper, or fund acquisitions on a short-term basis. Many of the transactions are unfunded credits and are seldom used. For this reason, most of the lenders' income comes from a facility or 'non-use' fee, and the lenders do not earn much interest income;

2. Leveraged loans - are a subset of corporate loans and are those generally with noninvestment grade ratings (BBB- or below). A loan also qualifies as leveraged even if the borrower is rated investment grade or not rated at all, but the loan is backed by security and has a spread of Libor +125 basis points or higher. These loans are more risky than the investment grade loans and are sometimes viewed as speculative-grade instruments. For the higher risk they carry, they also attract higher yield and attract higher interest rates than investment grade loans. The leveraged borrowers have significantly less access to the public market alternatives, and thus loans are their best financing alternative. Such loans are made to finance companies that are making acquisitions or large capital expenditures, refinancing, or making dividend payments to shareholders. The loans are attractive to the lenders for several reasons. First, because of the higher interest income and higher front-end fees, even if the risk of default is higher than for investment grade loans; this also makes them attractive as a basis for building investment portfolios in collateralized debt obligations and collateralized loan obligations. Secondly, because the interest rate is periodically set above LIBOR, it keeps pace with changing interest rates. Thirdly, such loans are usually secured by the borrower's assets and are further protected by covenants in the loan agreement. Covenant protection enables the lenders to monitor the borrower's activities and reset conditions of the loan along the way if the covenants are breached. Collateral protection enhances the chances of full recovery in case of default. As a result, leveraged loans are more attractive as investments than, for example, high-yield bonds (Mugasha, 2007).

Despite the high rate of return, investment-grade loans dominated in the structure of syndicated lending. During 2015 it's accounted for $74 \%$ of the syndicated loan, which is $7 \%$ higher than in 2014. According to leading experts, the reduction of the syndicated lending in 2015 was caused by a reduction in leveraged loans, which are more sensitive to changes in market conditions. Stock crisis in China, the continuation of the crisis in Greece, the fall in oil and energy prices, prolonged uncertainty of the US Federal system on the level of interest rates and its increasing, ultimately, were the main factors influencing the of the global market development of syndicated lending during 2015.

\section{Regional features of the market}

The most of foreign information agencies reflecting the statistics of the global market of syndicated lending, share it on three major regions - the Americas, Asia (also includes Australia and the Pacific) and the EMEA (Europe, Middle East and Africa). Considering the development of syndicated lending within the specified regions, it can be seen that over the past decade the largest by volume and number of transactions is the American market (figure 2).

The leading role in the American market plays the US, where during 2015 was raised USD 2,342bn and carried out 4,155 transactions. However, the market showed a drop by $1.4 \%$, which was mainly caused by the change in approaches to the borrowers. The uncertainty of the Federal Reserve and increasing interest rates have led to rapid reduction in the share of leveraged loans and increasing investment grade portfolio in the Q4. Previously, banks were actively providing revolving facilities, but in recent years there has been a tendency to issue term loans (71\% vs. $29 \%)$.

Although relationship remains an important driver in the investment grade space, its relative weight in the decisionmaking process has dropped significantly (today, only $31 \%$ of banks prioritize relationship over return vs. 59\% a year ago), while return on capital has become a top priority for $63 \%$ of lenders vs. only one third last year. However, the enhanced focus on return on capital has not translated into higher pricing due to the abundant liquidity available in the market, and pricing has remained stable since the beginning of the year. Rather, it has led to more volatility

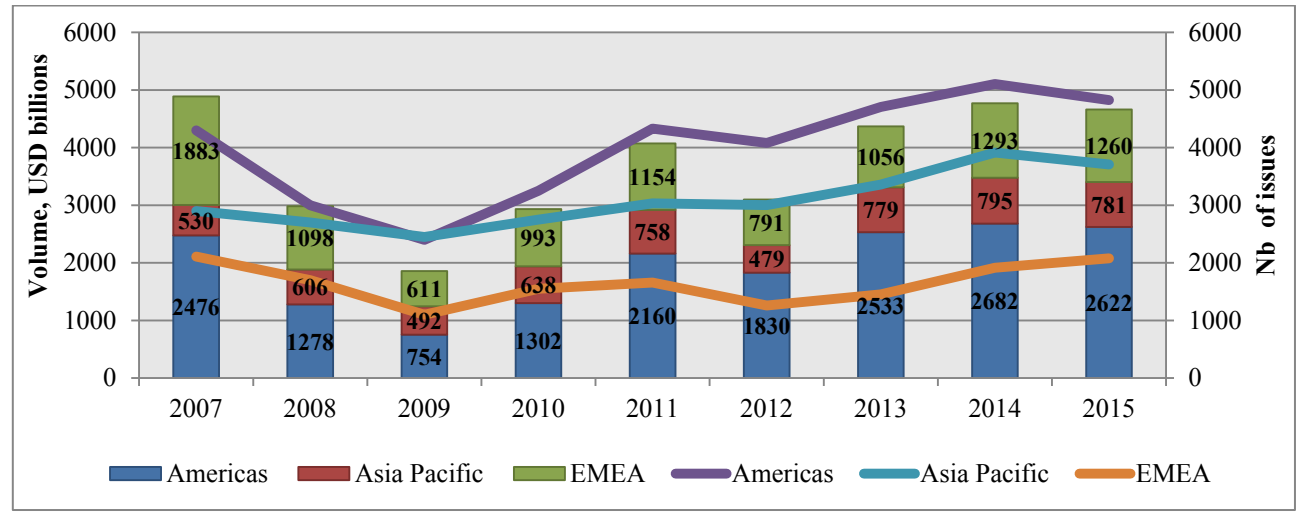

Fig. 2. Regional structure of the global market of syndicated lending

Source: Bloomberg Finance L.P., 2015, Thomson Reuters, 2015 
in bank groups and less predictable behavior by banks in any given transaction (Societe Generale, 2015). The largest transactions that have taken place in the market, were implemented in the second half of this year, and were used to finance $M$ \& A transactions. Among the banks a major player in the market served Bank of America Merrill Lynch, which also received the championship of the global market (Thomson Reuters, 2015).

On the second place after the American market is an EMEA market, which also showed a decline of $2.6 \%$ during 2015, which was caused by the reduction of lending in the European market. In total, during the year on the European market were held 1,849 transactions for the total amount USD 1,093 bln. The Eastern European market continued to decline, due to the continuation of economic sanctions against the Russian Federation and the Western European market showed a sharp decline (in the range of 20-50\%) in Germany, France, UK and the growth to $70 \%$ in Belgium, Spain, Italy. The vast majority of large European corporations have already refinanced their transactions over the last two years, so we are seeing an increasing share of mid-caps and non-investment companies in the current deal flow as they seek to take advantage of favorable market conditions. In particular, a number of mid-cap companies are launching inaugural syndicated facilities, diversifying away from traditional reliance on bilateral lines with their historical banks (Societe Generale, 2015).

A key trend in 2014 was the emergence of cov-lite loans in Europe. This trend has continued to develop in 2015: the Q1-Q3 2015 European institutional cov-lite new issuance volume totaled EUR 13.3bn. Although it fell behind the EUR $14.7 \mathrm{bln}$ issued over the same period in 2014 , it represented a bigger share of institutional level (45\% in January-September 2015 vs. only 39\% in JanuarySeptember 2014). Covenants are undertakings given by a borrower as part of a term loan agreement. Their purpose is to help the lender ensure that the risk attached to the loan does not unexpectedly deteriorate prior to maturity. Covenants may, for example, place restrictions on merger activity or on gearing levels. Breach of a covenant normally constitutes an event of default and, as a result, the loan may become repayable upon demand. (Fight, 2004). It is expected that new cov-lite deals will continue to flow in the European market going forward.
The market of the Middle East and Africa in contrast to the American and European markets has demonstrated rapid growth during 2015 (growth was 77\%). Despite the difficult geopolitical situation and the fall in oil prices the Islamic lending market was quite stable. It should be noted that the Islamic lending refers to specific types of loans. Islamic syndicated loan is loan for which the bank is not allowed to charge any interest. However, the financial institution shall be entitled to receive income from lending other way. For example, it may become a party to an equity-funded project, fully sharing the risks and the awards of enterprise. Also, the bank has the right to participate in trade, to earn income from the difference between the cost and the selling price. At the same time, under Sharia law investment in the production and sale of alcohol, drugs, weapons, etc. are not allowed. Any trade agreement should be based on the principle of justice and should not presume illegal enrichment of either party.

Taking into account high interest of investors and activities of international organizations (such as International Finance Corporation, the World Bank) the African market of syndicated lending is steadily growing in recent years.

Last year was also characterized by slowdown in the so-called "Chinese factor" (the Chinese market of syndicated lending in recent years has demonstrated high growth). In connection with the stock market crisis, credit markets in Asia has shown decline of $16 \%$. Together with the reduction of the development of the Chinese market, there has been a drop in lending markets of India and Australia, due to the suspension of financing of individual projects and transferring them to the next fiscal year (Societe Generale, 2015). The Japanese market continues to be one of the most stable markets in recent years and is ranked second by number of transactions after the US.

Based on analysis of the syndicated loan features in the different countries of the world, we have compiled the segmentation of the global market of syndicated lending in the regional context by the following features - the average amount of the deal, loan term, the main industry and the share of foreign capital (Table 1). As can be seen from Table 1, in highly developed countries syndicated loans are characterized by short-term, large amounts, and a smaller share of foreign capital (US, Canada, Western Europe, Japan), in developing countries, these values are opposite.

Table 1

Features of syndicated loans in different regions of the world

\begin{tabular}{|c|c|c|c|c|}
\hline Region & $\begin{array}{c}\text { The average amount of } \\
\text { transactions, USD mln }\end{array}$ & Loan period, years & Priority sector (\%) & $\begin{array}{c}\text { The share of foreign } \\
\text { capital in the market, } \%\end{array}$ \\
\hline US and Canada & 550,0 & 4 & Energy (18\%) & 32,0 \\
\hline Latin America & 380,0 & 6 & Materials (29\%) & 93,3 \\
\hline Western Europe & 600,0 & 5,5 & Energy (18\%) & 68,4 \\
\hline Eastern Europe & 450,0 & 5 & & 92,2 \\
\hline Middle East and Africa & 725,0 & 7,5 & Financials (30\%) & 78,0 \\
\hline Asia and Australia & 335,0 & 5,5 & Industrials (21\%) & 67,0 \\
\hline Japan & 110,0 & 4 & 17,0 \\
\hline
\end{tabular}


US and European leadership are achieved by consistently high demand for loans of this type, which are supported by three main factors. Firstly - is a significant integration of national markets to international market, which allows local banking institutions, carrying out operations, make a profit, not only on the national market, as well as in other markets. Secondly - syndicated loan provides to borrowers an alternative choice between bond and bilateral bank loans, providing an opportunity to attract large-scale resources to finance capital projects. And the thirdly - standardized rules, regulations and standardized procedures for documentary support syndication loans in the primary market and the secondary market infrastructure that allow lenders to resell syndicated loans. Speaking about markets of developing countries, the defining features of these markets are a significant level of risk and therefore increased profitability and comparable instability, which leads to crises that are overcome with the help of official creditors and international financial institutions.

In turn, syndicated loans are a new source of foreign loan resources, and thus contribute to an increase in investments in emerging markets. Syndicated financing accord to the national banking institutions opportunities for diversification as sources of income, as well as risks leading to financial stability, which is a fundamental issue for emerging markets. A key role in the processes of intensification in such markets assigned to international organizations, such as the European Bank for Reconstruction and Development (EBRD), International Finance Corporation (IFC), the Asian Development Bank and the Bank for International Settlements. Taking into account the volume of loans, we can definitely say that the leading role on the market played by the IFC.

\section{Market forecast}

Carried out analysis of the current state of the global syndicated loan market on the example of different regions makes it possible to formulate the main trends in the development of this market and forecast its development in the short term. Based on data from previous years and due to the construction of the approximation lines it can be assumed that the volume of syndicated lending during 2016 will continue to grow, but rather a slow pace - in the range of $6-8 \%$, and end of the year will be about USD $5,000 \mathrm{bn}$. The main factors that will contribute to the growth of syndicated lending will be:

- high liquidity in the American and European markets, which will contribute to capacity leveraged lending and, together with the spread of cov-lite deals could lead to an increase in syndicated lending in the American and European markets to $10 \%$ and $5 \%$ respectively;

- increasing lending in the African region through the international organizations, will compensate for the decline of Islamic lending through the sharpening geopolitical situation; in fact the market will remain at the same level with a slight increase (about 2-3\%);

recovering of Asian market through the implementation of the agreements that had been postponed in 2015 in India and Australia, as well as the continuation of $\mathrm{M} \& \mathrm{~A}$ deal that took place in previous years; approximate growth will be in the range of $3-4 \%$.

\section{Conclusion}

During the last decade the global market of syndicated lending grew almost twice and continues to grow. In conditions of economic globalization, syndicated loans acquire the dynamic development and become one of the most influential factors that affect the growth of the economy and increasing the country's competitiveness in world markets. Taking into account the peculiarities of the development of syndicated lending in different regions of the world, its segmentation was carried out. It was found that the level of economic development depends on such factors as the term of the loan, the amount and the share of foreign capital in lending. Based on analysis of major economic events that took place during 2015 and their impact on the market, as well as taking into account lending characteristics in certain regions, the development of the syndicated loan market in the short term was predicted.

\section{References}

Bloomberg Finance L.P. (2015). Global syndicated loans. Retrieved from http://www.bloomberg.com/ professional/content/uploads/sites/4/Bloomberg-Global-Syndicated-Loans-League-Tables-20151.pdf

Fight, A. (2004). Syndicated lending - London: Elsevier Butterworth-Heinemann, 208 p.

Mugasha, A. (2007). The law of multi-bank financing. Syndicated loans and secondary loan market - New York: Oxford University Press Inc., 84 p.

Societe Generale. (2015). Debt capital markets 2015 review and 2016 forecast. Retrieved from http://cib.societegenerale.com/uploads/tx bisgnews/SG_CIB_DCM 2015_Review and_2016_Forecast.pdf Thomson Reuters. (2015). Global syndicated loans review. Retrieved from http://share.thomsonreuters.com/ general/PR/Loan-4Q15-\%28E\%29.pdf

World Bank. (2015). Global Financial Development Report 2015: Long-Term Finance. Retrieved from http://www-wds.worldbank.org/external/default/WDSContentServer/WDSP/IB/2015/09/02/090224b0830 b28d/2_0/ Rendered/PDF/Global0financi0000long0term0finance.pdf 


\section{Назар MOPO3}

\section{РЕГИОНАЛЬНЫЕ ОСОБЕННОСТИ РАЗВИТИЯ МИРОВОГО РЫНКА СИНДИЦИРОВАННОГО КРЕДИТОВАНИЯ}

Аннотация. Целью работы является исследование и анализ современных тенденций мирового рынка синдицированного кредитования, характеристика его региональной структуры, выявление специфических признаков и особенностей в отдельных регионах мира и определение основных направлений дальнейшего развития мирового рынка синдицированного кредитования. Методика. Исследование основано на статистической информации из открытых источников отдельных стран по отношению к рынку синдицированного кредитования. Данные также были получены с сайтов ведущих рейтинговых агентств, исследующих развитие синдицированного кредитования. Также, при исследовании вопроса использовались аналитические экономические статьи и материалы исследований ведущих зарубежных ученых по вопросам развития синдицированного кредитования в мире. Результаты исследования показали, что развитие рынка синдицированного кредитования в последние годы характеризуется: стремительным наращиванием объемов и количества сделок; определяющим влиянием США и стран Западной Европы на динамику рынка; активными действиями международных финансовых организаций на рынках развивающихся стран; упрощением условий кредитных договоров; укрупнением основных параметров кредитования - суммы сделки и общего срока кредитования. Динамику мирового рынка синдицированного кредитования и его доходность определяет соотношение между спекулятивными и инвестиционными кредитами, развитие которых зависит от общеэкономической ситуации на рынке. На основе проанализированных факторов влияния на рынок установлено, что в краткосрочном периоде рынок будет продолжать расти, но достаточно медленными темпами. Практическое значение. Изучение рынка синдицированного кредитования дает возможность лучше понять механизм функционирования современного финансового сектора. Особого внимания, на наш взгляд, заслуживают рынки развивающихся стран, которые имеют значительный потенциал роста. Значение/оригинальность. Впервые было осуществлено сегментацию мирового рынка синдицированного кредитования на основе следующих критериев - сумма сделки, срок кредита, отрасль и доля иностранного капитала. Полученные результаты исследования будут способствовать лучшему использованию зарубежного опыта для построения системы синдицированного кредитования в стране, превратив его в эффективный инструмент финансирования реального сектора экономики. 